\title{
Tinjauan Kritis Studi Life Cycle Assessment (LCA) di Indonesia
}

\author{
Mochammad Chaerul ${ }^{1, *}$, Venessa Allia ${ }^{2}$ \\ ${ }^{1,2}$ Program Studi Teknik Lingkungan, Fakultas Teknik Sipil dan Lingkungan, \\ Institut Teknologi Bandung \\ *Koresponden email: m.chaerul@ ftsl.itb.ac.id
}

Diterima: 9 Desember 2019

Disetujui: 11 Desember 2019

\begin{abstract}
Life Cycle Assessement (LCA) studies in Indonesia have developed since last few years with a various product system studied. This paper aims to provide a critical review of LCA studies that have been performed in Indonesia, which is expected to improve the quality of study in Indonesia in the future. Scope of the study was limited to papers published in national journals and traced through the Indonesian Publication Index website from year of 2010 to 2016. There were 17 LCA studies reviewed, including the studies for renewable energy products, plantation, waste management, water treatment, and several products' manufacturing etc. Various critical issues found that need further attention to improve the quality of research LCA including the narrow LCA boundary, functional units, data inventory and allocation procedures, the conclusion that exceeds the results of the study, application of uncertainty analysis and sensitivity analysis, and transparency of the report.
\end{abstract}

Keywords: Life Cycle Assessement, critical review, Indonesia Publication Index, quality of study

\begin{abstract}
Abstrak
Studi Life Cycle Assessement (LCA) di Indonesia mulai menunjukkan peningkatan dalam beberapa tahun terakhir dengan variasi sistem produk yang diteliti. Paper ini bertujuan untuk memberikan tinjauan kritis terhadap berbagai studi LCA yang sudah dilakukan di Indonesia sehingga diharapkan dapat meningkatkan kualitas studi LCA di Indonesia di masa depan. Lingkup penelitian yang ditinjau dibatasi pada penelitian LCA yang diterbitkan pada jurnal nasional dan ditelusuri melalui situs Indonesian Publication Index dari tahun 2010 hingga 2016. Terdapat 17 studi LCA di Indonesia yang diterbitkan pada jurnal nasional berdasarkan penelusuran tersebut, diantaranya terkait produk energi terbarukan, perkebunan, pengelolaan sampah, pengolahan air dan berbagai produk manufaktur. Beberapa permasalahan kritis yang perlu mendapat perhatian lebih jauh untuk peningkatan kualitas studi LCA di Indonesia, antara lain: ruang lingkup yang terlalu sempit, unit fungsional, data inventori dan prosedur alokasi yang tidak dijelaskan, penarikan kesimpulan yang melebihi hasil kajian, penerapan analisa ketidakpastian dan analisa sensitivitas, dan transparansi laporan.
\end{abstract}

Kata Kunci: Life Cycle Assessement, tinjauan kritis, Indonesian Publication Index, kualitas studi

\section{Pendahuluan}

Berbagai macam kegiatan manusia berpotensi menimbulkan dampak negatif terhadap lingkungan. Potensi dampak negatif tersebut bukan saja diakibatkan karena proses produksi di suatu lingkungan industri, tetapi bisa saja diakibatkan karena ekstraksi bahan alam sebagai bahan baku, penggunaan produk itu sendiri, limbah yang dihasilkan setelah penggunaan suatu produk, dan lain-lain. Klasifikasi dampak yang dapat dihasilkan nya pun beraneka macam, sehingga diperlukan diperlukan suatu studi yang komprehensif, diantaranya dengan menggunakan metode Life Cycle Assessment (LCA).

Berdasarkan definisi yang tertulis pada ISO 14040 tahun 2006, LCA merupakan metode untuk mengevaluasi input, output dan potensi dampak lingkungan pada daur hidup suatu sistem produk [1]. LCA dapat digunakan untuk mengidentifikasi dampak lingkungan yang positif atau negatif dari suatu proses atau produk, menemukan peluang untuk pengembangan proses dan produk, membandingkan serta menganalisa beberapa proses berdasarkan dampak lingkungan yang ditimbulkan serta secara kuantitatif menghitung dampak lingkungan dari suatu produk [2]. LCA menjadi studi yang lebih rinci dibandingkan dengan konsep life cycle thinking yang sifatnya lebih general dan kualitatif dalam mempertimbangkan implikasi cradle-to-grave pada berbagai kegiatan [3]. Penerapan konsep LCA dalam berbagai produk juga sesuai dengan Sustainable Development Goals (SGDs) terkait produksi dan konsumsi berkelanjutan, atau dikenal dengan istilah SDGs nomor 12. SDG nomor 12 memiliki tujuan terkait peningkatan kesejahteraan melalui aktivitas ekonomi yang mereduksi penggunaan sumber daya alam serta mendegradasi pencemaran di sepanjang siklus hidup [4]. 
Tidak seperti kebanyakan negara maju di dunia, negara-negara berkembang dinilai kurang mampu memanfaatkan potensi metode Life Cycle Assessment (LCA) untuk membantu pembangunan yang berkelanjutan. Kapasitas LCA pada negara-negara berkembang dinilai masih kurang terkait rendahnya ketertarikan sektor industri dan pemerintah pada pengembangan LCA [5]. Hal yang sama juga terjadi di Indonesia sebagai salah satu negara berkembang yang saat ini termasuk dalam 10 besar negara pengemisi gas rumah kaca tertinggi. Emisi gas rumah kaca di Indonesia diprediksi akan naik dari 2,1 hingga 3,3 $\mathrm{GtCO}_{2} \mathrm{e}$ antara 2005 hingga 2030, dengan sumber emisi terbesar berasal dari perubahan fungsi lahan dan kehutanan, energi, kebakaran lahan gambut, sampah, pertanian dan industri [6]. Potensi pemanasan global merupakan salah satu kategori dampak lingkungan yang dapat dikuantifikasi oleh metode LCA.

Berdasarkan informasi pada situs Indonesia Life Cycle Assessment Network (ILCAN), kajian LCA di Indonesia saat ini masih dalam tahap awal perkembangan dan diketahui jumlah publikasi ilmiah terkait LCA di Indonesia relatif lebih rendah dibandingkan negara-negara Asia Tenggara lainnya. Namun kajian LCA di Indonesia mulai menunjukkan tanda peningkatan dalam lima tahun terakhir dengan variasi sistem produk yang diteliti diantaranya meliputi minyak sawit, biodisel, bioethanol, kompos, bensin, mini hydro power, gula, kopi, kacang-kacangan, ikan, udang, sapi, semen, kuningan, aluminium, gedung, hingga sepeda motor [6]. Dalam menilai dampak lingkungan suatu sistem produk, LCA terdiri dari empat prosedur utama sebagaimana yang ditunjukan oleh Gambar 1. Kotak di gambar tersebut mengindikasikan tahapan prosedur dan tanda panah menunjukan urutan proses, sedangkan tanda panah putus-putus mengindikasikan kemungkinan proses berulang [3].

Paper ini bertujuan untuk memberikan tinjauan kritis terhadap berbagai penelitian LCA yang sudah dilakukan di Indonesia sehingga diharapkan dapat meningkatkan kualitas penelitian LCA di masa depan terutama terkait kesesuaian dengan persyaratan dan standar prosedur LCA yang telah diakui secara global.

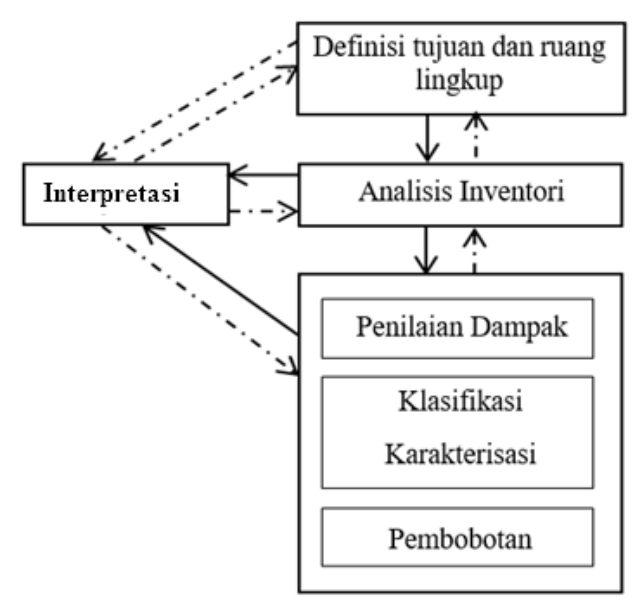

Gambar 1. Prosedur standar studi LCA

\section{Metodologi Penelitian}

Lingkup penelitian yang ditinjau dibatasi pada penelitian LCA yang diterbitkan pada jurnal nasional dan ditelusuri melalui situs Indonesian Publication Index atau dikenal sebagai Portal Garuda (http://garuda.ristekdikti.go.id/) dari tahun 2010 hingga 2016. Tinjauan kritis terhadap penelitianpenelitian LCA di Indonesia dilakukan berdasarkan panduan yang dijelaskan pada buku panduan "The Hitch Hiker's Guide to LCA" [3] dan sesuai dengan ISO 14044:2006 terkait persyaratan dan panduan LCA. Kriteria kritis yang ditinjau, yaitu (1) Kesesuaian metodologi, (2) Validitas kesimpulan, (3) Transparansi laporan.

1. Kesesuaian Metodologi

Kriteria ini meliputi penilaian terhadap metodologi, misalnya mencakup kesesuaian unit fungsional, ruang lingkup, prosedur alokasi, kalkulasi, penilaian dampak, tipe data, serta asumsi-asumsi yang digunakan dengan tujuan dari studi LCA.

2. Validitas Kesimpulan

Dengan mempertimbangkan hasil pengolahan data kuantitatif, limitasi studi serta faktor ketidakpastian, validitas kesimpulan menjadi kriteria kritis dalam studi LCA. Kesimpulan penelitian LCA yang valid harus didukung oleh hasil penelitian dan tidak melebihi limitasi studi yang sudah diidentifikasi sebelumnya. 
3. Transparansi Laporan

Laporan LCA harus dibuat secara transparan dan mengikuti persyaratan laporan yang tertulis pada dokumen normatif, misalnya sesuai dengan standar ISO 14040 tahun 2006.

\section{Hasil dan Pembahasan}

\subsection{Identifikasi Studi LCA di Indonesia}

Berdasarkan penelusuran yang dilakukan pada situs Indonesian Publication Index, terdapat 17 jurnal penelitian LCA yang diterbitkan pada jurnal nasional dari tahun 2010 hingga 2016. Tabel 1 menunjukan rangkuman 17 penelitian LCA yang telah ditinjau.

Sistem produk pada jurnal penelitian LCA di Indonesia cukup bervariasi, mulai dari bidang bioenergi, perkebunan, peternakan, akuakultur, pengelolaan sampah, pengolahan air dan berbagai macam produk manufaktur. Setiap jurnal selanjutnya ditinjau berdasarkan 3 kriteria kritis yaitu kesesuaian metodologi, validitas kesimpulan dan transparansi laporan.

Tabel 1. Rangkuman paper tentang LCA di Indonesia yang ditelusuri melalui situs Indonesian Publication Index

\begin{tabular}{|c|c|c|}
\hline No. & Penulis & Fokus Penelitian \\
\hline 1. & Ansori dan Hartini, 2014 & LCA produk kipas angin \\
\hline 2. & Gunamantha et al., 2010 & LCA pengelolaan sampah \\
\hline 3. & Harjanto et al., 2012 & LCA pabrik semen \\
\hline 4. & Hendrawan et al., 2010 & LCA daur ulang plastik \\
\hline 5 . & Hidayatno et al., 2011 & LCA produksi biodisel dari minyak sawit \\
\hline 6. & Ma'in et al., 2013 & LCA budidaya udang vaname \\
\hline 7. & Nisa et al., 2015 & LCA produksi biji kakao \\
\hline 8. & Palupi et al., 2014 & LCA produk kertas \\
\hline 9. & Pringgajaya dan Udisubakti, 2012 & LCA produk lampu \\
\hline 10. & Putri et al., 2014 & LCA produk susu KUD \\
\hline 11. & Riyanty dan Indarjanto, 2015 & LCA pengolahan air \\
\hline 12. & Rosmeika et al., 2010 & LCA pengolahan ampas tebu \\
\hline 13. & Sari et al., 2012 & LCA produk batik \\
\hline 14. & Siregar et al., 2013 & LCA produksi biodiesel \\
\hline 15. & Wulan et al., 2015 & LCA perkebunan sagu, sawit dan padi \\
\hline 16. & Yani et al., 2012 & LCA pabrik gula tebu \\
\hline 17. & Yani et al., 2013 & LCA kemasan botol PET \\
\hline
\end{tabular}

\subsection{Kesesuaian Metodologi}

\section{Ketersediaan dan Kerepresentatifan (representativeness) Data}

Kerepresentatifan LCA dipengaruhi oleh tiga aspek yaitu geografi, lingkup waktu dan teknologi yang digunakan [8]. Penelitian LCA untuk berbagai siklus hidup produk di Indonesia selayaknya menggunakan data yang berasal dari negeri sendiri, namun belum tersedianya life cycle inventory (LCI) milik Indonesia membuat kebanyakan penelitian LCA di Indonesia menggunakan basis data (database) negara lain yang telah menyusun LCI. Salah satu basis data yang banyak digunakan adalah Ecoinvent [9, 10, 11]. Dari ribuan inventori yang terdapat pada basis data Ecoinvent versi 3.3 hanya menyebutkan sekitar 32 inventori yang berasal dari Indonesia [12]. Perbedaan geografi serta perkembangan teknologi di negara maju dan negara berkembang akan mempengaruhi kerepresentatifan LCA dalam memodelkan suatu siklus produk dan menjadi limitasi studi yang perlu disebutkan.

\section{Ruang lingkup}

Untuk dapat menggambarkan daur hidup suatu produk, ruang lingkup menjadi faktor yang kritis dalam penelitian LCA. Dari keseluruhan penelitian yang ditinjau, tidak ada penelitian yang menggambarkan satu daur hidup produk secara utuh, dari proses ekstraksi bahan alam hingga akhir hidup produk (cradle-to-grave). Ketersediaan data untuk menggambarkan proses cradle-to-grave menjadi salah satu faktor yang membatasi. Gambar 2 menunjukan tipe ruang lingkup (cradle-to-grave, cradle-to-gate, gate-to-gate) yang diterapkan pada berbagai penelitian LCA di Indonesia. 


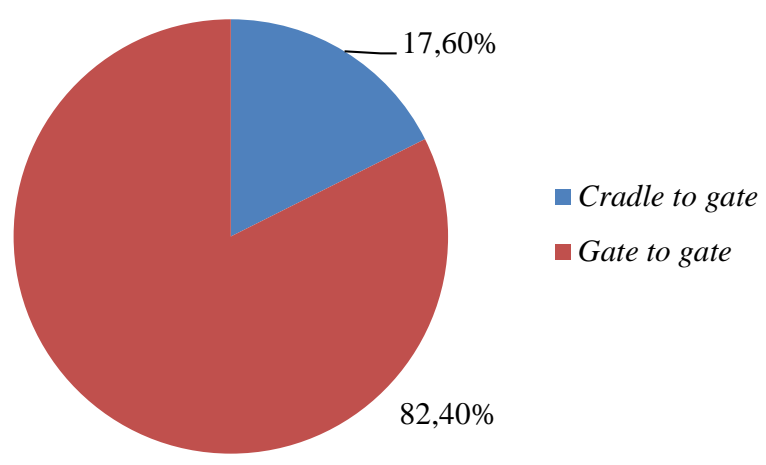

Gambar 2. Tipe ruang lingkup berbagai penelitian LCA di Indonesia yang ditinjau

\section{Unit Fungsional dan Inventori Data}

Kesesuaian metodologi juga sangat terkait dengan penetapan unit fungsional dan penjelasan inventori data. Beberapa penelitian LCA di Indonesia yang ditinjau telah dapat menggambarkan perspektif daur hidup (life cycle perspective) suatu produk namun tidak menjelaskan unit fungsional dan inventori data yang digunakan dalam metode LCA. Di beberapa penelitian, tidak menjelaskan unit fungsional yang digunakan padahal menurut standar ISO 14040:2006, dampak lingkungan yang potensial dari suatu produk bersifat relatif berkaitan dengan unit fungsional yang digunakan penelitian $[13,14,15$, $16,17]$. Penelitian lainnya menyebutkan unit fungsional yang digunakan namun tidak menjelaskan data inventori produk untuk setiap unit fungsional dan hanya menjelaskan inventori berupa persentase komposisi material penyusun produk [9].

\section{Prosedur Alokasi}

Faktor kritis lain terkait metodologi LCA adalah prosedur alokasi pada sistem yang memiliki lebih dari 1 output produk. Pada penelitian tentang produksi gula tebu, diagram alir penelitian menunjukan bahwa output proses produksi gula diketahui berupa gula SHS (super high sugar) dan molase, namun penulis tidak menjelaskan metode alokasi yang dilakukan untuk menghitung produk gula SHS [16].

\section{Pemilihan Kategori Dampak Lingkungan}

LCA merupakan metode untuk menganalisa dampak lingkungan secara kuantitatif [2]. Kategori dampak lingkungan juga menjadi faktor kritis pada tahapan Life Cycle Impact Assessment (LCIA), karena dampak lingkungan yang dipilih harus mendukung tujuan dan ruang lingkup penelitian LCA yang sudah didefinisikan sebelumnya [3]. Metode LCA dapat digunakan untuk menganalisa berbagai dampak lingkungan dari suatu produk, namun beberapa penelitian hanya fokus pada dampak pemanasan global terkait emisi $\mathrm{CO}_{2}[18,19]$. Pemilihan dampak pada kedua penelitian tersebut telah sesuai dengan tujuan dan ruang lingkup penelitian, namun salahsatu penelitian menggunakan banyak asumsi penyederhanaan dalam memodelkan sistem gate-to-gate transportasi sampah plastik dan proses daur ulang plastik, karena hanya memperhitungkan bahan bakar fosil sebagai input dan emisi $\mathrm{CO}_{2}$ sebagai output [18]. Penyederhanaan seperti ini menimbulkan pertanyaan apakah studi tersebut dapat dikategorikan sebagai studi LCA atau hanya pemodelan emisi $\mathrm{CO}_{2}$ dari bahan bakar fosil saja.

\section{Pembobotan}

Faktor kritis lainnya dalam pengukuran dampak lingkungan adalah aplikasi pembobotan pada fase LCIA. Jika studi LCA mengaplikasikan teknik pembobotan maka perlu dijelaskan metode pembobotan yang digunakan [3]. Dari keseluruhan penelitian yang ditinjau, terdapat 3 penelitian yang menyertakan teknik pembobotan dalam LCIA dengan menggunakan metode Eco-Cost 2012 [9, 10], serta menggunakan metode Eco-Cost 2007 [20].

\section{Teknik Pengolahan Data}

Saat ini terdapat berbagai perangkat lunak (software) yang dikembangkan untuk memudahkan proses pengolahan data pada kajian LCA, baik untuk menggambarkan siklus produk yang rumit atau untuk menghitung dampak lingkungan. Penggunaan perangkat lunak komersial yang menyediakan berbagai basis data juga lazim digunakan pada kajian LCA di Indonesia. Gambar 3 menunjukan grafik persentase penggunaan berbagai perangkat lunak sebagai teknik pengolahan data yang dilakukan pada penelitian LCA di Indonesia. Terdapat penelitian yang mengembangkan software tersendiri untuk menganalisa dampak lingkungan dari pengolahan ampas tebu menjadi energi [21]. Pada penggunaan 
software komersial, sangat penting untuk menyebutkan nama dan versi dari software yang digunakan, namun masih terdapat penelitian yang tidak mempublikasikan hal tersebut [22].
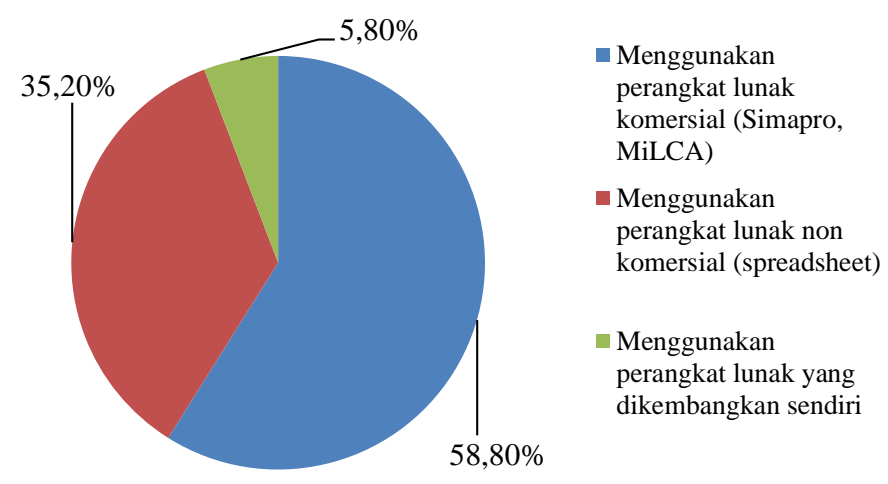

Gambar 3. Penggunaan perangkat lunak pada penelitian LCA di Indonesia yang ditinjau

Sebanyak 17,6\% penelitian LCA yang ditinjau telah cukup rinci menggambarkan siklus produk dari proses ekstrasi bahan alam hingga akhir gerbang produksi (cradle-to-gate) [23, 24, 25]. Sementara $82,4 \%$ penelitian lainnya mengambil lingkup proses produksi atau ekstraksi suatu produk saja (gate-togate). Lingkup gate-to-gate masih menimbulkan pertanyaan apakah dapat disebut sebagai penelitian LCA atau tidak, karena lebih tepat disebutkan sebagai model lingkungan dari suatu industri [3]. Sebagai alternatif untuk melebarkan lingkup gate-to-gate, terdapat penelitian yang memasukan proses transportasi bahan baku dari penyuplai ke pabrik dan proses distribusi produk dari pabrik ke pembeli [13].

\subsection{Validitas Kesimpulan}

\section{Kesesuaian Kesimpulan dan Ruang Lingkup}

LCA memanfaatkan informasi dalam LCI dan LCIA untuk membangun sebuah kesimpulan dari suatu proses dan membuat rekomendasi yang sesuai dengan hasil penelitian [2]. Penarikan kesimpulan menjadi faktor yang sangat kritis, karena kesimpulan tidak hanya harus dibangun berdasarkan hasil yang mendukung, namun juga tidak boleh melebihi limitasi-limitasi dalam lingkup studi. Salahsatu penelitian menghasilkan kesimpulan yang diluar lingkup hasil dan pembahasan dimana pada kesimpulan menyatakan kegiatan siklus kemasan botol PET berpotensi menimbulkan pemanasan global, penipisan lapisan ozon dan hujan asam, sementara pembahasan LCIA tidak menjelaskan dampak lingkungan dari satu siklus kemasan botol PET, melainkan hanya menyebutkan dampak lingkungan global dari proses produksi kemasan botol PET dan botol gelas saja. Hal ini menunjukan penarikan kesimpulan tidak didukung oleh hasil analisa LCIA [17].

\section{Analisa Ketidakpastian (Uncertainty) dan Analisa Sensitivitas}

Validitas kesimpulan dalam LCA juga dapat didukung oleh analisa ketidakpastian dan analisa sensitivitas. Gambar 4 menunjukan persentase penerapan analisa ketidakpastian dan analisa sensitivitas pada penelitian LCA di Indonesia yang ditinjau.

Dari keseluruhan penelitian LCA yang ditinjau hanya total $11,76 \%$ penelitian LCA yang ditinjau yang melakukan analisa ketidakpastian atau analisa sensitivitas. Analisa ketidakpastian dilakukan dengan cara membandingkan antara beberapa metode indikator dampak, dimana studi LCA ini membandingkan tiga metode dampak lingkungan yaitu CML 2B-2000, Eco-Indicator 95 dan Impact 2002 [11]. Alasan pemilihan metode pun dijelaskan pada pembahasan sehingga menguatkan validitas kesimpulan. Analisa sensitivitas dilakukan untuk mengobservasi sensitivitas hasil ketika ada perubahan-perubahan dalam asumsi. Hal ini dilakukan dengan membuat beberapa skenario alternatif dengan variasi parameter tertentu yang berbeda dari skenario dasar [11].

Terdapat penelitian dimana analisa sensitivitas dilakukan dengan cara membuat analisis variasi komposisi bahan organik pada aliran sampah mengikuti pola variasi $50 \%, 55 \%, 60,99 \%, 65 \%$, dan 70\%. Hasil simulasi menunjukkan bahwa variasi fraksi organik sampah tidak mempengaruhi urutan terhadap kinerja lingkungan sehingga menambah tingkat keyakinan pada kesimpulan [26]. 


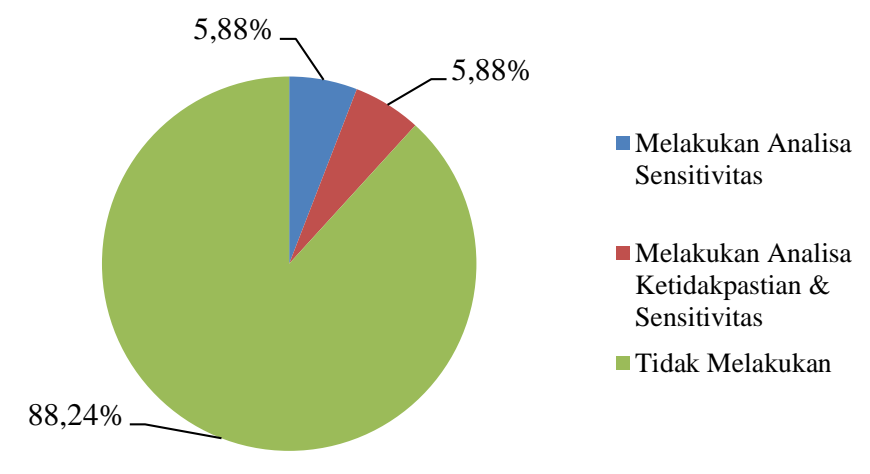

Gambar 4. Analisa ketidakpastian dan sensitivitas penelitian LCA di Indonesia yang ditinjau

\subsection{Transparansi Laporan \\ Keterulangan (Reproducibility)}

Faktor keterulangan (reproducibility) penelitian menjadi salah satu faktor yang sangat penting dalam penelitian LCA sehingga laporan penelitian LCA perlu mengandung seluruh informasi yang memungkinkan peneliti lain untuk mengulang studi dan menghasilkan hasil yang sama. Seluruh data, metode, asumsi dan limitasi harus dilaporkan secara transparan sehingga pembaca dapat memahami kompleksitas dari studi yang dilakukan serta menggunakan hasil penelitian LCA secara konsisten sesuai dengan tujuan studi. Tidak berarti semua data harus dituliskan secara aktual dalam laporan namun dapat juga mengacu kepada dokumen lain yang transparan dan mudah diakses [3].

Masalah transparansi data masih banyak ditemui pada kajian LCA yang ditinjau, terutama terkait data inventori yang tidak dilaporkan $[13,14,15,16,20]$. Beberapa kajian LCA lainnya dapat dijadikan contoh terkait kejelasan unit fungsional, informasi data inventori yang rinci untuk setiap unit fungsional, serta asumsi-asumsi yang digunakan [11, 19, 23, 25].

Pada kajian LCA juga biasanya menggunakan kombinasi antara data primer dan data sekunder sehingga sumber data perlu disebutkan dengan jelas yang telah menjabarkan sumber-sumber data yang digunakan pada LCI [24]. Asumsi dan limitasi yang digunakan juga perlu dilaporkan, yang menyatakan data listrik berdasarkan database software dan limitasi input infrastruktur yang hanya menghitung material HDPE dan pipa PVC [11]. Masalah transparansi data menjadi tantangan tersendiri bagi penelitian LCA di Indonesia, mengingat masih rendahnya ketertarikan sektor industri dalam penelitian LCA membuat banyak industri masih resisten dalam mempublikasikan data, sehingga data-data industri yang digunakan dalam penelitian seringkali bersifat rahasia dan terbatas untuk dipublikasikan.

\section{Kesimpulan}

Terdapat 17 penelitian LCA di Indonesia yang diterbitkan pada jurnal nasional dan ditelusuri melalui situs Indonesian Publication Index dari tahun 2010 hingga 2016. Seluruh penelitian ini memiliki sistem produk yang cukup bervariasi, mulai dari bidang bioenergi, perkebunan, peternakan, akuakultur, pengelolaan sampah, pengolahan air, dan berbagai macam produk manufaktur. Pada penelitian-penelitian ini masih ditemukan berbagai permasalahan kritis yang perlu mendapat perhatian lebih jauh untuk peningkatan kualitas penelitian LCA di Indonesia, antara lain: 1) Ketidaksesuaian metodologi terkait ruang lingkup yang terlalu sempit, pemodelan LCA yang melibatkan terlalu banyak penyederhanaan, serta unit fungsional, data inventori per unit fungsional dan prosedur alokasi yang tidak dijelaskan, 2) Validitas kesimpulan terkait adanya penarikan kesimpulan yang melebihi hasil kajian dan masih jarangnya kajian LCA di Indonesia yang menyertakan analisa ketidakpastian dan analisa sensitivitas, serta 3) Transparansi laporan terutama terkait tidak semua kajian LCA di Indonesia melaporan data secara rinci sehingga sulit bagi peneliti lain untuk menilai atau mengulang studi yang sama.

\section{Daftar Pustaka}

[1] International Standards Organization, 2006. Environmental Management - Life Cycle Assessment Principles and Framework ISO 14040, ISO Press.

[2] A. S. Williams, "Life Cycle Analysis: A Step by Step Approach" Diakses dari: < http://www.istc.illinois.edu/info/library_docs/tr/tr40.pdf>. (10 November 2016). 2009.

[3] H. Baumann and A. M. Tillman, "The Hitch Hiker's Guide to LCA". Lund: Holmbergs. 2004. 
[4] UN, "Sustainable Development Goals: 17 Goals to Transform The World. United Nation" Diakses dari: <http://www.un.org/sustainabledevelopment/sustainable-consumption-production/> $\quad(10$ November 2016). 2016.

[5] T. Ramjeawon, "Building Capacity for Life Cycle Assessment in Developing Countries. Life Cycle Assessment Handbook: A Guide for Environmentally Sustainable Products", Scrivener Publishing LLC. 2012

[6] S. Thamrin, "Indonesia's National Mitigation Actions: Paving the Way towards NAMAs - Discussion Document". Diakses dari: https://www.oecd.org/env/cc/48304156.pdf. (10 November 2016). 2011.

[7] ILCAN, "Workshop on Life Cycle Assessment Research in Indonesia 2015". ILCAN. Diakses dari: <http://www.ilcan.or.id/events/wolcari-2015/>. (10 November 2016). 2015.

[8] European Commission - Joint Research Centre - Institute for Environment and Sustainability, "International Reference Life Cycle Data System (ILCD) Handbook - General guide for Life Cycle Assessment - Detailed guidance". Edisi ke-1. EUR 24708 EN. Luxembourg: Publications Office of the European Union. 2010.

[9] M. Ansori dan S. Hartini, "Konsep Produk Kipas Angin Multi Fungsi 3 In 1 Sebagai Strategi Penurunan Biaya Dampak Lingkungan Berbasis Life Cycle Assessment (LCA)". Industrial Engineering Online Journal. 3(4), pp: 1-6, 2014.

[10] F. Nisa, A. T. Sutanhaji, B. Suharto, dan S. Widyotomo, "Penentuan Tingkat Eko-efisiensi Proses Produksi Biji Kakao Menggunakan Life Cycle Assessment Pada Unit Produksi di Pusat Penelitian Kopi dan Kakao Indonesia”. Jurnal Sumber Daya Alam dan Lingkungan. 2(2), pp:32-39, 2015.

[11] M. Ma'in, S. Anggoro, dan S. B. Sasongko, "Kajian Dampak Lingkungan Penerapan Teknologi Bioflok pada Kegiatan Budidaya Udang Vaname dengan Metode Life Cycle Assessment". Jurnal Ilmu Lingkungan. 11(2), pp:110-119, 2013.

[12] J. B. Guinee, "LCA (Analisa Siklus Hidup) Past, Present, Future \& Perspective for South East Asia/Indonesia". Makalah disajikan dalam $2^{\text {nd }}$ Conference Series on Life Cycle Assessment, Universitas Pelita Harapan, Tangerang, Indonesia, 2-3 November 2016. 2016

[13] A. H. Palupi, L. P. Tama, R. A. Sari, "Evaluasi Dampak Lingkungan Produk Kertas dengan Menggunakan Life Cycle Assessment (LCA) dan Analytic Network Process (ANP) (Studi Kasus: PT X Probolinggo)", Jurnal Rekayasa dan Manajemen Sistem Industri. 2(5), pp:1136-1147, 2014.

[14] R. P. Putri, L. P. Tama, R. Yuniarti, "Evaluasi Dampak Lingkungan pada Aktivitas Supply Chain Produk Susu KUD Batu dengan Implementasi Life Cycle Assessment (LCA) dan Pendekatan Analytic Network Process (ANP)" Jurnal Rekayasa dan Manajemen Sistem Industri. 2(4), pp:684695, 2014.

[15] F. P. E. Riyanty dan H. Indarjanto, "Kajian Dampak Proses Pengolahan Air di IPA Siwalanpanji Terhadap Lingkungan dengan Menggunakan Metode Life Cycle Assessment (LCA)", Jurnal Teknik ITS. 4(2), pp:86-90, 2015.

[16] M. Yani, I. Purwaningsih, M. N. Munandar, "Penilaian Daur Hidup (Life Cycle Assessment) Gula pada Pabrik Tebu". E-Jurnal Agroindustri Indonesia. 1(1), pp:60-67, 2012.

[17] M. Yani, E. Warsiki, N. Wulandari, "Penilaian Daur Hidup Botol PET (Polyethylena Terephtalate) pada Produk Minuman". Jurnal Bumi Lestari. 13(2), pp:307-317, 2013.

[18] H. Hendrawan, K. Dowaki, dan U. S. Putro, "An Analysis of the $\mathrm{CO}_{2}$ Emission Abatement in Plastic Recycling System Using Life Cycle Assessment (LCA) Methodology: A Case Study of Bandung City, Indonesia”. Indonesian Journal for the Science of Management. 9(3), pp:245-251, 2010.

[19] S. Wulan, H. Kusnoputranto, J. Supriatna, H.M.H.B. Djoefrie, H. M. Al Hakim, "Life Cycle Assessment of Sago Palm, Oil Palm, and Paddy Cultivated on Peat Land". Indonesian Journal of Wetlands Environmental Management. 3(1), pp:14-21, 2015.

[20] D. P. Sari, S. Hartini, D. I. Rinawati, T. S. Wicaksono, "Pengukuran Tingkat Eko-efisiensi Menggunakan Life Cycle Assessment untuk Menciptakan Sustainable Production di Industri Kecil Menengah Batik". Jurnal Teknik Industri. 14(2), pp:137-144, 2012.

[21] Rosmeika, L. Sutiarso, B. Suratmo, "Pengembangan Perangkat Lunak Life Cycle Assessment (LCA) untuk Ampas Tebu (Studi Kasus di Pabrik Gula Madukismo, Yogyakarta)”. AGRITECH. 30(3), pp:168-177, 2010.

[22] K. A. Pringgajaya dan C. Udisubakti, "Implementasi Life Cycle Assessment (LCA) dan Pendekatan Analytical Network Process (ANP) untuk Pengembangan Produk Hetric Lamp yang Ramah Lingkungan”. Jurnal Teknik ITS Vol. 1(1). 2012 
[23] T. R. Harjanto, M. Fahrurrozi, dan L. M. Bendiyasa, "Life Cycle Assessment Pabrik Semen PT Holcim Indonesia Tbk. Pabrik Cilacap: Komparasi antara Bahan Bakar Batubara dengan Biomassa". Jurnal Rekayasa Proses. 6(2), pp:51-57, 2012.

[24] A. Hidayatno, T. Y. M. Zagloel, W. W. Purwanto, Carissa, L. Anggraini, "Cradle to Gate Simple Life Cycle Assessment of Biodiesel Production in Indonesia". Makara Teknologi. 15(1), pp:9-16, 2011.

[25] K. Siregar, A. H. Tambunan, A. K. Irwanto, S. S. Wirawan, T. Araki, "Perbandingan Penilaian Siklus Hidup (Life Cycle Assessment) Produksi Biodiesel Secara Katalis dari Crude Palm Oil dan Crude Jatropha Curcas Oil”. Jurnal Teknologi Industri Pertanian. 23(2), pp:129-141, 2013.

[26] M. Gunamantha, F. Fandeli, S. D. Tandjung, S. Sarto, "Life Cycle Assessment Pilihan Pengelolaan Sampah: Studi Kasus Wilayah Kartamantul Propinsi D.I Yogyakarta". Jurnal Manusia dan Lingkungan. 17(2), pp:78-88, 2010. 